\title{
HUBERT József
}

\section{ADOMÁNYGYÜJTÉS, IMPULZUSADOMÁNYOZÁS A KÖZÖSSÉGI MÉDIÁBAN}

Az interneten, különösen az olyan web 2.0 alkalmazásokon, mint amilyenek az egyes közösségimédia-oldalak is, a jótékonysági szervezetek egy sor olyan eszközhöz férnek hozzá, melyek alkalmazása révén korábban nem tapasztalt lehetőségek tárháza nyílik meg számukra az emberek megszólítására és adománygyújtő kampányok lefolytatására. Ennek a lehetôségnek a kiaknázása ugyanakkor speciális szakértelmet és felkészültséget követel meg a szervezetek részéról. Ezt támasztja alá a szakirodalomi áttekintés, melynek alapján leszögezhető: a közösségimédia-felületeken egészen eltérő motivációból és másként adnak az emberek, mint más, ,offline"/hagyományos csatornákon.

\section{Kulcsszavak: közösségi média, nonprofit, adományozás}

2012 márciusában az „Invisible Children” nevú jótékonysági szervezet egy új kampányt indított. A gyermekek jogait védő csoport célja az volt, hogy egy ugandai háborús búnös, Joseph Kony ${ }^{1}$ brutalitására ráirányítsa a nemzetközi közvélemény figyelmét. A 'Kony 2012' névre keresztelt kampány rövid távú célja az volt, hogy a kegyetlen mészáros viselt dolgait megismerhessék az emberek világszerte, emellett azt is szerették volna elérni, hogy a férfit már 2012 év végéig elfogják a hatóságok. A videó néhány nap leforgása alatt az egyik legsikeresebb víruskampány lett: több millió nézót vonzott, három hét múlva pedig már az Egyesült Államok szenátusában is Kony volt a téma. A kampánytól szintén nem függetlenül az Afrikai Unió az év március végén egy ötezer fős nemzetközi hadtest felállítását jelentette be, melynek föbb feladatai közé tartozott Joseph Kony felkutatása és igazságszolgáltatás elé állítása (Guo Saxton, 2014)

A kampányt általában mindenütt hatalmas sikerként értékelték, és szinte mindent felvonultat, ami a nonprofit szervezetek közösségi média használata mellett felsorakoztatható. A videó pillanatok alatt virálissá vált (3 nap alatt több millió nézőt vonzott, a tanulmány írásakor két közösségi videómegosztó oldalon összesen mintegy 120 millió megtekintést generált). A kampány már az első napokban áttörte a közösségi média falát, a tömegmédiába bekerült, sőt napokra tematizálta is azt. Ennek fényében már nem meglepő, de összességében sikernek nevezhető az is, hogy szinte páratlan gyorsasággal (2-3 hét alatt) az ügyben érintett legfontosabb döntéshozókat is cselekvésre késztette.

Mégis felmerül a kérdés: valóban sikersztoriként könyvelhetjük el a Kony 2012 kampányt? Megállapítható, hogy a tágabb közvélemény érdeklődését pusztán néhány napon át sikerült fenntartani, ahogy ez kiderül az 1. ábráról.

\section{A ,Kony 2012' kampány aggregált nézettségi} adatai a YouTube-on, a közzétételt követő egy hét során (millió összes megtekintés)

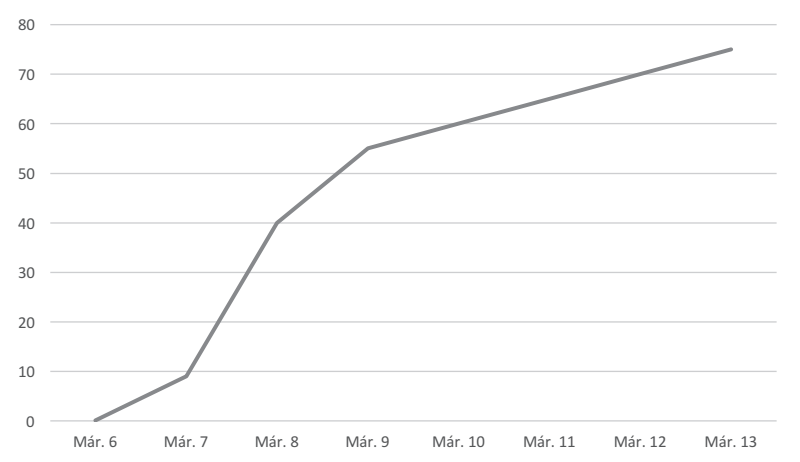

Forrás: http://www.telegraph.co.uk/news/worldnews /joseph-kony/9134431/Kony-2012-Stats-breakdown-of-the-viral-video.html

Az internetes közegben szokatlanul hosszú, közel 30 perces videó nézettsége egy hét alatt megközelítette a 
80 milliót - az ezt követő több, mint 4 év során már alig 25 millióval volt képes tovább bővülni. A kampány folytatásaként készült 'Kony 2012 - Part II'-t már alig egy hónappal a kirobbanó sikert elérő első részt követôen közzétették. Mégsem sikerült meglovagolni annak népszerúségét: az új rész nézettsége töredéke volt a réginek, 4 év alatt a hárommillió megtekintést sem érte el.

A kampány mögött álló Invisible Children nevú szervezetet számos szakmai kritika érte: a videóban közölt tények egy része ugyanis nem pontosan fedte a valóságot, és elhangoztak olyan vádak is, mi szerint a kampány során gyújiött pénzek tekintélyes részét saját múködésük finanszírozására fordították - és nem a kampánycél megvalósítására.

Ha alaposabban megvizsgáljuk a jelenséget, akkor már koránt sem egyértelmú, hogy milyen sikerek füződnek a kampányhoz, és megkérdőjelezhető a videó kapcsán sokat emlegetett erő, a közösségi média ereje. A videó vírusszerú terjedése ugyanis kimutathatóan azt követôen indult meg, hogy az elsők között egy, a tömegmédiából ismert sztár, Oprah Winfrey is megosztotta 11 milliós követőtáborával a videót (majd több más, a közösségi médiában milliós követőbázissal rendelkező sztár is követte ôt).

De a legfontosabb kérdőjelet a kampány sikeressége kapcsán az jelenti, hogy négy évvel a videó közzétételét követôen a brutális vérengzésekért, kínzásokért felelős Joseph Kony még mindig szabadlábon van.

A mostani tanulmánynak egyik célja, hogy áttekintést biztosítson a közösségi média és a nonprofit szektor korántsem egyértelmú kapcsolatáról. Az elmúlt években az akadémiai szféra részéről is növekvő érdeklődés övezi a témát (pl. Greenberg - MacAulay, 2009; Saxton - Wang, 2014; Paulin et al., 2014; Ilten, 2015 stb.), ugyanakkor egyes szerzők azt is megállapították: az érdeklődés sokszor deskriptív jellegú, az iparág közösségimédia-használati szokásainak bemutatására szorítkozik, a mélyebb, háttérben meghúzódó összefüggések feltárásának az igénye nélkül (Guo - Saxton, 2013). A korábbi kutatások többsége emellett inkább a közösségi média kommunikációs célú felhasználására fókuszál, miközben a nonprofit szervezetek túlélése szempontjából az adománygyújtés legalább ennyire, ha még nem sokkal inkább fontos kérdés.

A tanulmányban a megelőző kutatások áttekintését követôen főként azt a kérdést vizsgálom, hogy menynyiben és milyen módon alkalmas a közösségi média adománygyújtő platformként szolgálni a harmadik szektor szereplői számára. Ahhoz, hogy erról átfogó képet alkothassunk, a problémát szervezeti oldalról és az egyének irányából is vizsgálni szükséges. Ahogyan az a szakirodalmi áttekintésből is kitűnik majd: mindkét dimenzió egyaránt fontos a téma elmélyült megértéséhez. A tanulmányban azonban csak az utóbbi témá- ra vonatkozóan állítok fel modellt, melynek részleges tesztelésére került sor.

A tanulmány felépítése a következő:

1. először a nonprofit szervezetek közösségimédia-használatával kapcsolatos tényezóket, szokásokat tekintem át, ami a szervezeti feltételeket érinti, majd

2. az egyéni perspektíva kerül fókuszba, az adományozók jellemzőit, közösségimédia-használati szokásait vizsgálom meg, végül

3. az adományozás egyéni motivációit egy érdekes, a szakirodalomban még kevéssé kutatott keretben, az impulzusadományozások szintjén vizsgálom. A szakirodalmi áttekintésre építve egy elméleti keretet állítok fel, melynek részleges empirikus tesztje zárja a kutatást.

\section{Közösségi hálózatok használata a nonprofit szektorban}

A közösségi hálózatokat - Kaplan - Haenlein 2010-es cikkével egyező módon - a web 2.0 részeként értelmezem, a web 2.0 az a platform, ami talajt biztosít a közösségi média evolúciója számára (Kaplan - Haenlein, 2010, p. 61.). A közösségi hálózatok építőelemei:

a. felhasználók által generált tartalom (user generated content - UGC),

b. a felhasználók saját (valamennyire publikus) profiljai,

c. a felhasználók virtuális kapcsolatokat hozhatnak létre,

d. a rendszeren belüli szabad navigálás, a mások által létrehozott tartalmak, kapcsolódások megtekintés (Stenger - Coutant, 2010; Kaplan - Henlein, 2010).

Fontos kiemelni, hogy bár alapvetôen technológiai jellegú fejlődésról van szó (pl. szükséges volt hozzá az adatfeldolgozó és -tároló kapacitások gyors fejlódése, a felhasználók közötti idóben szinkron kommunikációt lehetôvé tevő alkalmazások fejlesztése stb.), számunkra elsősorban mégis nem a technikai-múszaki fejlódés dimenziója áll az érdeklódés homlokterében, hanem ennek társadalmi, üzleti vetülete (O'Reilly, 2005).

A közösségi hálózatok terjedésétől sokan a nonprofit szektor megerősödését várták, de legalábbis azt remélték, hogy ezek a szervezetek hatékonyan képesek lesznek saját ügyük szolgálatába állítani a web 2.0 „forradalommal” megnyíló lehetőségek tárházát. Az is igaz, hogy ez nem pusztán lehetôség, de bizonyos fokú kényszer is. A harmadik szektor szereplóinek minden eszközt meg kell ragadniuk ahhoz, hogy az általuk 
képviselt ügyet sikerre vihessék: napjainkban egyre növekvő verseny a nonprofit szervezetek közt a szúkös erőforrások megszerzéséért, a kormányzati, valamint a szélesebb nyilvánosság támogatásának megszerzéséért (White - Peloza, 2009), miközben egyes szerzők szerint például az egyik legfóbb támasznak számító kormányok mind kisebb támogatást tudnak és képesek biztosítani számukra (Paulin et al., 2014).

A kutatások ugyanakkor azt mutatják, hogy a nonprofit szféra lassabban fordult rá a web 2.0 váltásra: Waters et al. (2009) azt találták, hogy miközben például a Facebook-profilhoz tartozó alapvető információkat kielégítő mértékben adták meg magukról ezek a szervezetek, addig a közösségi hálózatok igazi erejét, az információ disszeminációra való képességét már csak kevesebben aknázták ki (a mintájuk csupán 44 százaléka), és multimédiás tartalmakat (videó, hang stb.) még ennél is kevesebben alkalmaztak (25 százalék).

Waters (2009) megállapítása szerint a nonprofit szervezetek lemaradtak a közösségi média adoptációjában, amit a szerző azzal magyaráz, hogy a szervezetek másokra várnak, hogy mások tapasztalatai alapján építsék ki saját közösségimédia-jelenlétüket. Későbbi kutatások ugyanakkor a közösségimédia-platformok növekvő felhasználásáról számoltak be a harmadik szektor szereplői körében (Saxton - Wang, 2014).

Miközben mind a nonprofit szektor, mind a közösségi média az akadémiai kutatások homlokterében van, a két terület kapcsolódását már sokkal kevesebb kutatás jellemzi. Miközben - ahogyan azt a fentiekben bemutattam - a web 2.0 és különösen a közösségi hálózatoktól új távlatok nyitását várták akár a kommunikáció, a kapcsolattartás, a közösségszervezés vagy éppen a témánk fókuszában álló adománygyưjtés kapcsán is, ezek részletes bemutatása és feltárása még nem történt meg.

\section{Nonprofit szervezetek és a közösségi média}

A közösségi média a nonprofit szektor szereplői számára széles körú alkalmazási lehetőségekkel bír. A szervezetek múködésének érintettjeivel (lakosság, ügyfelek, adományozók, alkalmazottak, törvényhozás és kormányzat, valamint önkéntesek, a szervezet ellenzói stb.) való stratégiai kommunikáció (Saxton - Guo, 2014) révén ezek a szervezetek hatékonyabbak lehetnek az érdekképviseleti munkában (Guo - Saxton, 2013) és nagyobb lehetőséget kapnak a közösség építésében (Briones et al., 2011.) stb.

Waters et al. (2010) kutatása egy másik érdekes lehetôségre is rámutat: a nonprofit szervezetek akár a tömegmédiába is újszerú irányból hatolhatnak be a közösségi média révén. Ilyen lehetôség például az, amikor a szervezet web 2.0 profiljait követô újságírók figyelnek fel a szervezet tevékenységére és emelik be azt a napi sajtóba (a szerző́k ezt a jelenséget a „média elcsípésének" nevezik). Több szerzó is amellett érvel, hogy a közösségi média révén a nonprofit szektor szereplói a kereskedelemben ismert impulzusvásárlások mintájára „impulzusadományokhoz” juthatnak (Saxton - Wang, 2014; Ilten, 2015 stb.).

A közösségi média alkalmazásával a harmadik szektorhoz tartozó szervezetek kommunikációs költségei is számottevően csökkentek. Hudson és Thal (2013) kimutatták, hogy az online értékelések ingyenes, a szervezetek számára vonzó reklámlehetőséget biztosítanak. Az üzenetek összeállításának, valamint a célcsoportokhoz történő, célzott eljuttatásának költsége is csökkent (Saxton - Guo, 2014). Online közegben a döntéshozatalban vagy a szervezet múködésében érintett csoportok bevonása is jóval költséghatékonyabb (Saxton et al., 2010). A szervezetek önkéntes bázisa is könnyebben mobilizálható, a dialógusra szélesebb lehetőségeket kínálnak a web 2.0 alkalmazások - még akkor is, ha nagyobb számú tömegről beszélünk (Guo - Saxton, 2014). Több kutatás is (Saxton - Wang, 2014; Gandía, 2011 stb.) bemutatta, hogy a közösségi média révén a nonprofit szervezetek új, nagyobb és a hagyományosnál fiatalabb célcsoportokat szólíthatnak meg költséghatékony módon. A közösségi média révén nemcsak hogy fiatalabb, de az adományozás szempontjából még „érintetlen” célcsoportok is bevonhatók, akik az átlagosnál nagyobb összegeket ajánlanak fel (Flannery et al., 2009).

A nonprofit szervezetek által nyújtott visszacsatolás az adományok célba juttatásáról fontos marketingeszköz lehet az adományok gyújtésében is, az embereket természetes, hogy érdekli: mi lett az adományaik sorsa (a kutatások affektív, kognitív és morális tényezőket is feltártak a jelenség motivációjaként lásd Ye et al., 2015).

Ezek a lehetôségek mind abba az irányba mutatnak, hogy a nonprofit szervezetek a közösségi média alkalmazása révén nemcsak egyoldalú információközlést és/ vagy -fogadást valósíthatnak meg, hanem közösségépítést is.

Bár mint láttuk, a közösségi média számos vonzó tulajdonsággal bír, melyek a nonprofit szervezeteket ezek alkalmazására sarkallhatják, ezzel párhuzamosan számos veszéllyel is számolniuk kell a harmadik szektor szereplőinek az új közegben.

Az új média használatának terjedését ugyanakkor egy sor tényező is gátolja, melyek közül az alábbiak a legfontosabbak a jótékonysági szervezetek számára:

- szervezeti korlátok, képességbeli, illetve tudásbeli hiányosságok,

- erőforrás-korlátok (idő, pénz) (Rowlands et al., 2011), melyek érinthetik a tartalmak elóállítását, illetve a beérkező kérések feldolgozását, kezelését, 
- adatvédelmi és biztonsági aggályok,

- copyright, szerzői jogvédelemmel kapcsolatos aggályok (Collins - Hide, 2010),

- adminisztrációval kapcsolatos követelmények, hiányosságok (Picazo - Vale et al., 2012).

Ugyanakkor jelentős változásként (előrelépésként) értékelhető, hogy az infokommunikációs eszközök fejlődésével és terjedésével a pénzügyi eszközök ma már nem jelentenek gátló tényezót a technológia által nyújtott lehetőségekhez való hozzáféréshez, mint volt ez akárcsak másfél, két évtizeddel korábban (Saxton Wang, 2014).

Már az első idókben feltúnt úgy a kutatóknak, mint a közösségi médiát stratégiai eszközként használó nonprofit szervezeteknek az angolban csak „slacktivism” ${ }^{2}$ vagy „clicktivism” névvel illetett jelenség. Ez egy speciális, csak az online közegben értelmezhetô jelenség: az aktivisták valódi segítségnyújtás helyett kattintásaikkal igyekeznek ,segíteni” a számukra fontosnak ítélt ügyet (pl. online petíció aláírása, tartalom vagy oldal megosztása, like a Facebookon stb.). Shulman (2009) kutatásában egy, a környezetvédelmi szabályozásokban a participatív demokrácia elveit a gyakorlatba ültetó online kormányzati portálra érkező, több százezer hozzászólást elemezve megállapította, hogy „bizonyos jelek abba az irányba mutatnak, hogy a nagy volumenú online mozgósítás rossz minőségú, de megszakítás nélkül érkező üzenetek áradatát szabadítja rá az ügynökségekre" (Shulman, 2009, p. 26.). Morozov szerint a ,slacktivism” jelenti az aktivizmus ideáltipikus formáját egy lusta generáció számára (Morozov, 2009).

Megjegyzendo, hogy egyes kutatók a „slacktivism” vagy „clicktivism” jelenség mögött is pozitív jelentéstartalmat tártak föl. Karpf (2010) például amellett érvel, hogy az ilyen részvételi formák kritikusai önálló kampánykezdeményezésként kezelik például az online petíciókat, miközben ezek sokkal inkább egy átfogó stratégia egyedi elemeként ragadhatók meg. Bowers (2010) szerint még a slacktivism-típusú kampányok is alkalmasak:

1. demonstrálni az ügy mögött álló tömegek nagyságát,

2. erósíteni a lobbitevékenységet,

3. a potenciális támogatókról listát generálni jövőbeli akciókhoz.

Témánk, az online adományozás szempontjából ugyanakkor azt mondhatjuk: a slacktivism valóban komoly veszélyforrást jelenthet az online adományozás számára. Egyes nagyobb nonprofit szervezetek már kampányelemként a reklámstratégiába emelve utalnak a jelenségre (pl. Unicef: Likes don't save lives). A je- lenség elleni küzdelem jegyében már külön közösségi hálózat alakult (Horyou $\left.{ }^{3}\right)$, melynek célja, hogy a múvészeket, illetve a jótékonysági szervezeteket közvetlenül a cselekvésre, illetve az adományozásra kész önkéntesekkel kösse össze.

Egy másik fontos veszélyforrás a témában a szervezetek reagálási képességének nem kielégítő múködése, amit tömören le-, illetve kimaradásként jellemezhetünk. A szakirodalom alapján a közösségi média foghíjas használata a nonprofit szervezetek körében az alábbi főbb okokra vezethető vissza:

1. idő és emberi eróforrás hiánya - a közösségimédia-oldalak kezelése - eltéróen például a szervezeti honlapokétól - a megnyitást követően folyamatos és rendszeres frissítést igényel, valamint a beérkező kérdésekre, kommentekre történő reagálások is újabb erőforrásokat kötnek le,

2. szervezeti akadályok, különösen - a gyakran az idősebb generációhoz tartozó - testületi tagok ellenkezése,

3. a főként fiatalabb korosztályok számára vonzó közösségi média használata révén a nonprofit szervezetek egy része attól is tart, hogy a legfontosabb adományozói bázisnak számító idôsebb korosztályt elidegenítheti magától (Briones et al., 2011).

\section{Adományozói perspektíva: online adományozás és impulzusadományozás}

A fentiekben a témánk szempontjából releváns megelőző akadémiai kutatások bizonyos aspektusait már bemutattam, de elsősorban a közösségi média és a harmadik szektor kapcsolatára koncentrálva. Az impulzusadományozások természete, az ilyen típusú adományozás mögött meghúzódó pszichológiai, szociális és egyéb tényezők legalább ennyire fontosnak minősíthetók.

Bennett (2009) kiemeli: miközben az impulzusvásárlás fogalmát a szakirodalom már alaposan körüljárta, ennek jótékonysági környezetben való vizsgálatával a szakma még adós. A szerző szerint a téma fontosságát támasztja alá, hogy:

- a pszichológiai szakirodalomból világos, hogy az emberek rendszeresen döntenek impulzusszerúen,

- egyes kutatások alapján a vásárlások akár 50 százaléka történik ilyen módon, és

- nincs ok feltételezni, hogy a jótékonykodás terén ne állna fent hasonló reláció,

Egyes korábbi kutatások ráadásul abba az irányba mutatnak, hogy online vásárlás esetén az impulzív döntés sokkal intenzívebb módon van jelen, mint a „,normál” fogyasztói döntéshozatalban (Donthu - Garcia, 1999). 
Mejova et al. (2014) négy pontban összegzik azokat a tényezóket, amelyek az egyéneket befolyásolják az online adományozásban:

- egyéni kapacitások (emberi és pénzügyi), valamint hajlandóság,

- az egyén érdeklődési köre,

- az egyént érő társadalmi befolyások (melyek szerepe a szerzők szerint online közegben kevésbé jelentős, ugyanakkor a közösségi média fentebb bemutatott természetéből fakadóan feltehető, hogy a web 2.0-n ennek a szerepe - a közeg transzparens, mások számára is átlátható jellege miatt - nőhet),

- külső befolyásoló tényezők, például a nonprofit szervezetek reklámtevékenysége.

Az impulzusadományozást vizsgálva Bennett (2009) a személyes tényezők sorát egy érdekes dimenzióval, az érzelmek szerepével egészítette ki. Kutatásában pozitív (megerősítő) érzelmek elsősorban az adományozás következményeként jelennek meg (hangulat javulása, ,lelki” felemelkedettség stb.). Más kutatások alapján úgy tűnik: az érzelmek kettós szerepet játszanak a folyamatban, az adományozás előzményeként (antecedent) és következményeként (consequence) is megjelenhetnek. A szakirodalomban több olyan pozitív és negatív érzelmet is beazonosítottak már, melyek az adományozókban felmerülnek az adományozás folyamatában: büntudat (Hibbert et al., 2007), boldogság (Liu - Aaker, 2008), szimpátia (Small et al., 2007), empátia (Cryder Loewenstein, 2008) stb. Az ellentétes pólusú érzelmek eltérô módon ösztönzik az adományozást: az adományozók a felajánlás révén a negatív érzelmek (pl. búntudat, szégyen stb.) csökkenését, míg a pozitív érzelmek (pl. öröm) felszabadulását, növekedését kívánják elérni (Aaker et al., 2009). További fontos különbség, hogy pozitív érzelmek felszabadulása esetén az adományozás a felajánló önazonosságát (identitását) is érintheti, míg a negatív érzelmek esetén ilyen hatás csak ritkábban lép fel (Aaker - Akatsu, 2009).

Ugyanezen érzelmek azonban nemcsak előidézői, hanem következményei is lehetnek az adományozásnak az adakozók részéról. Felajánláskor az egyének azt is keresik, hogy a maguk részéről milyen hasznossága lehet ennek a cselekedetnek. A szakirodalom alapján az adományozásnak alapvetően két féle pozitív hozadéka létezhet:

1. az adományozót személyesen is érintő haszon (benefit to self - pl. egy rákkutatással foglalkozó alapítvány megosztja a kutatási eredményeit a jótékonykodókkal),

2. másoknak szóló haszon (benefit to others - pl. rákos betegek gyógyításával foglalkozó alapítvány valamilyen létfontosságú múszert/berendezést vásárol egy kórház számára).

Az érzelmi nyereséget az első kategóriába sorolhatjuk (Ye et al., 2014).

A szakirodalomban jól dokumentált jelenség, hogy az érzelmeknek az impulzusszerú vásárlási döntésekben központi szerep jut. Weiberg és Gottwold (1982) kutatása alapján az impulzusvásárlás során a fogyasztók magas szintú érzelmi aktivitást mutatnak, amit a hedonisztikus élvezetek dominálnak. Az érzelmek az impulzusvásárlás befolyásolásában is jelentős szerephez jutnak, más stimulusokkal (pl. hangulat, vásárlási környezet, társadalmi stimulusok stb.) együtt (Kanuk Schiffman, 2000).

A szakirodalom az érzelmek kettős szerepét tárja fel: az érzelmek az adományozás folyamatában előzményként és következményként is megjelennek. Az általam javasolt modellben én az utóbbiként szerepeltetem az adományozók érzelmeit.

\section{Az adományozás modelljei}

Ahogy azt már fentebb is leszögeztük: az adományozás gazdasági természetének vizsgálata nem új keletú jelenség. A következókben két modellt ismertetek, egyik egy hagyományos, közgazdasági megközelítésben írja le a jótékonysági felajánlásokat, míg a másik a közösségi médiára adaptálja azt.

\section{A korábbi modellek (economic model of giving)}

Weisbrod és Dominguez (1986) az adományozás közgazdasági modelljében a nonprofit szervezeteket közjavak elóállítónak látja, az általuk gyújiött adományok mértéke pedig a szervezet „termelése” (output) iránti aggregált kereslet egy proxy mutatójaként értelmezhető. A modell magyarázó változói az ár, a minőség és az információ: a piac kínálati oldalának szereplői az általuk ,,megtermelhető” legkedvezőbb ár-minőség kombinációt kínálják, és ezt reklámozzák annak érdekében, hogy még több hozzájárulást gyújtsenek.

- ár: az ügyre fordított költségek és az összes költség hányadosaként van kifejezve: például: egy szervezet ,ára”, ahol az adományok 80 százalékát fordítják programokra, 10-10 százalékot adminisztrációra és adománygyújtésre, 1,25 egység lesz (mivel $(0,1+0,1+0,8) / 0,8)=1,25)$,

- a minóséget a szerzők a szervezet korával becsülték (elismerve, hogy ez igazából tökéletlen proxy változó),

- az informálást pedig az adománygyújtéssel helyettesítették, feltételezve azt, hogy ennek szerepe a nonprofit szektorban hasonló ahhoz, amilyen sze- 
repet a reklámok töltenek be a for-profit szektorban.

A szerzők által felállított modell robosztusságát több tucatnyi kutatás és tanulmány támasztotta alá az elmúlt három évtizedben. Callen et al. (2003) például a modell tesztelése során azt találták, hogy a szervezet hatékonysága (minősége) meghatározó az adománygyújtés hatékonyságában: az erőforrásokat pazarló, technológiájában nem hatékony szervezetek kevesebb adományt tudnak gyújiteni, mint a hatékonyabban múködő csoportok. Ugyancsak összefüggést találtak a szervezet által közzé tett, valamint a könyvelési adatok pontossága, a szervezeti múködés hatékonysága és az adomány gyújtés hatékonysága között (Tinkelman - Mankaney, 2007). Más szerzők ugyanakkor szintén a fentebb bemutatott Weisbrod-Dominguez modell alapjaiból kiindulva arról is értekeznek: eltérés lehet a múltbeli (vagyis a számokkal már alátámasztható) hatékonyság, valamint a jövőben érkező adományok elköltésének hatékonysága közt (Roberts et al., 2005). Marudas (2009) szektoriális vizsgálata eltérő fontossági súlyokat talált a szervezeti hatékonyság (,minôség"), valamint az adománygyújtés számára a különbözô szektorokban múködő nonprofit szervezetek esetén. (1.táblázat)

\section{Az ár és a szervezeti hatékonyság relevanciája adománygyújtés szempontjából az egyes nonprofit szektorokban}

\begin{tabular}{|l|c|c|}
\hline & Ár releváns & $\begin{array}{c}\text { Ár nem } \\
\text { releváns }\end{array}$ \\
\hline $\begin{array}{l}\text { Hatékonyság } \\
\text { releváns }\end{array}$ & - & Filantrópia \\
\hline $\begin{array}{l}\text { Hatékonyság nem } \\
\text { releváns }\end{array}$ & Oktatás, Egészségügy & Múvészet \\
\hline
\end{tabular}

Forrás: Marudas (2009) alapján saját szerkesztés

\section{A közösségi média modellje}

Saxton és Wang amellett érvelnek, hogy a közösségi hálózatokon keresztül történő adományozás alapvetően más természetú, mint amit Weisbrod-Dominguez modellje leír. Modelljükben három tényező szerepel:

- közösségi hálózatok: a szervezet profiljához kapcsolódó emberek személyes hálózatán keresztül a relációsan beágyazott hálózati kapcsolódások kihasználásával exponenciális méretekben szólíthatóak meg újabb és újabb rétegek,

- szervezeti kapacitások: pénzügyi és webes képességek egyaránt magyarázni tudják a szervezeti adománygyújtés hatékonyságát, a szerző́k érvelése abból a szempontból is érdekes, hogy a nonprofit szervezet mérete, valamint a technológiahasználati és hozzáférési képességek, valamilyen módon egymás helyettesítőiként tudják magyarázni az adománygyújtési eredményeket,

- iparág: a szervezetek által gyújtött adományok volumene a múködési területük függvénye (Saxton Wang, 2014).

\section{A javasolt koncepcionális modell}

Mint azt láttuk, a korábban javasolt modellek mindegyike szervezeti megközelítésből azt vizsgálta, hogy milyen tényezők befolyásolják azt, hogy az egyes nonprofit szereplők mennyi adományt képesek gyújteni. Ezzel szemben az általam javasolt modellben (2. ábra) az adományozókat (,fogyasztókat”) vizsgálom, a pszichológiai kutatásokból vett előzmények, viselkedés és következmények típusú modellel

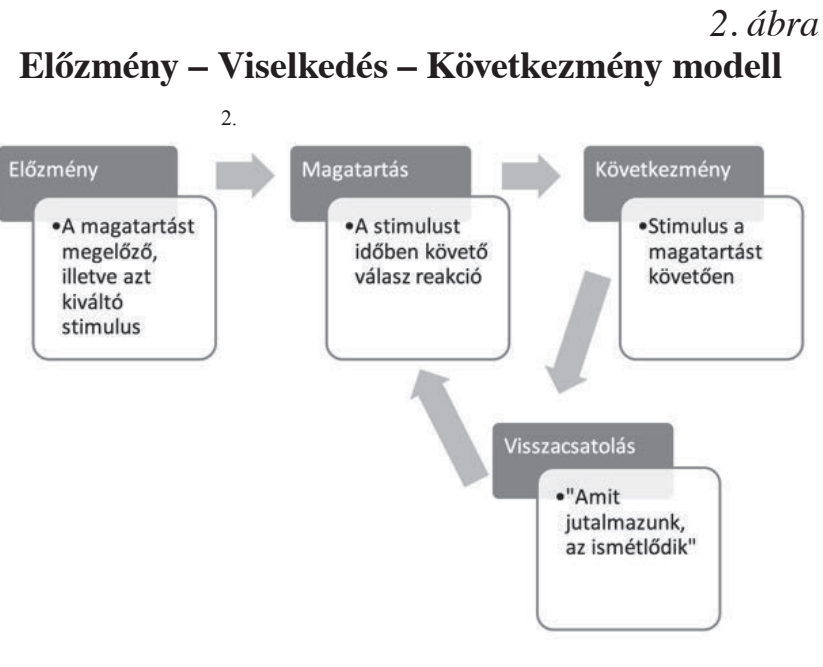

Forrás: Oliver (1980) alapján saját szerkesztés

Az impulzusadományozás terén mutatott „fogyasztói magatartás" elózményeként a korábbi kutatásokra támaszkodva három fontosabb tényezô csoportot határoztam meg:

- személyes/pszichológiai tényezők,

- anyagi tényezó,

- üggyel való azonosulás.

Ugyanakkor azt is feltételezem, hogy a magyarázó tényezők, valamint az impulzusadományozás közötti kapcsolatot bizonyos moderáló változók is befolyásolják. A teljes elméleti keretet (az előzmények - magatartás - következmények modell alapján) a 3. ábra szerint vázoltam fel. 


\section{Az impulzusadományozás javasolt elméleti kerete}

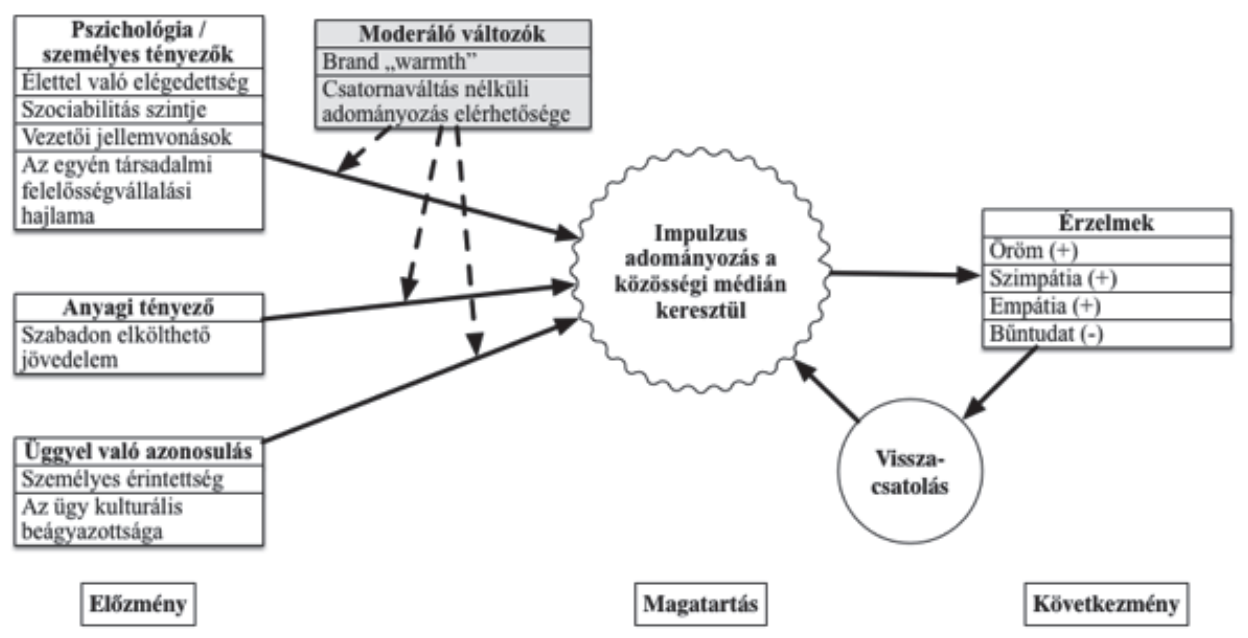

Forrás: saját szerkesztés meg: a személyes érintettség (ami a tudatosság növelésében is szerepet kaphat), valamint az adott ügy kulturális beágyazottságának a mélységében.

H3a. Az emberek hajlamosabbak impulzusszerú adományokat felajánlani olyan ügyek számára, melyek őket magukat személyesen és/vagy közvetlenül érintenek.

H3b. A kulturálisan beágyazott ügyeknek nagyobb támogatói bázisuk van.

\section{A moderáló változók}

Feltételezhetô, hogy az impulzusadományozással kapcsolatosan megfigyelhető fogyasztói (,,adomá-

\section{Pszichológiai és személyes tényezók}

A szakirodalomban jól dokumentált jelenség, hogy az egyéni pszichológiai jellemvonások jelentôsen befolyásolják a jótékonysági ügyekkel kapcsolatos interakciót (pl. kapcsolódás, részvétel, adományozás stb.). Vijaykumar et al. (2010) három tényezőt emelnek ki (H1a, H1b, H1c).

Hipotézis 1 . Az adományozó személyisége meghatározza az impulzusadományozásra való hajlandóságot.

H1a. Az élettel elégedett emberek inkább hajlamosak impulzív jelleggel adományokat adni.

H1b. A társas hajlam és az impulzusadományozás között pozitív összefüggés áll fenn.

H1c. A vezetői személyiségjegyekkel rendelkező emberek inkább hajlamosak impulzív jelleggel adományokat adni.

H1d. A nagyobb társadalmi felelősségvállalási hajlammal bíró emberek inkább hajlamosak impulzív jelleggel adományokat adni.

\section{Az anyagi tényezö}

Habár az impulzusadományok az egészen kicsi összegtől a nagyobbakig terjednek, feltételezhetô, hogy az adományozók anyagi háttere szintén fontos magyarázó változó. Ennek nagyságát nem abszolút mértékben, hanem a szabadon elkölthető jövedelemmel mérjük.

H2. A szabadon elkölthető jövedelem nagysága pozitív összefüggést mutat az impulzusadományozással.

\section{Az üggyel való azonosulás}

Az, hogy az adományozó milyen mértékben tud azonosulni egy-egy üggyel, szintén összefügghet az (impulzus) adományozással. Ezt két tényezőben ragadtam nyozói”) magatartás, valamint a fentebb bemutatott magyarázó tényezők közötti kapcsolatot külső tényezők is befolyásolják, melyeket a modellben a moderáló változók közé soroltam.

A szóba jöhető változók közül kettőt emeltem a modellbe:

- brand „warmth”, melyrôl korábbi kutatások már feltárták, hogy az egyik legerôsebb magyarázója lehet a fogyasztó-márka kapcsolatoknak a közösségimédia-térben (Bernritter et al., 2016), végül

- a csatornaváltás nélküli adományozás lehetősége várakozásaim (valamint előzetes kutatásom alapján is) komolyan befolyásolhatja az adományozási szándék konkrét tettekben való megtestesülését.

\section{Azérzelmek, mint következmények}

Ahogyan azt korábbi kutatások alátámasztják, a fogyasztók egy fontos motivációja az adományozás során különbözô érzelmi szükségleteik kielégítése, azaz bizonyos pozitív érzelmek erősödését, más, negatív érzelmek csökkenését várják attól. A modellemben (+) jellel jelöltem azokat a korábbi kutatásokban feltárt érzelmeket, melyek az előbb, míg (-) jellel azt, mely az utóbbi kategóriába eshet.

H4a. Az impulzusadományozás következményeként a pozitív érzelmek (öröm, szimpátia, empátia) erősödnek az adományozóban.

H4b. Az impulzusadományozás következményeként a negatív érzelem (bûntudat) szintje csökken az adományozóban. 


\section{A visszacsatolás}

A visszacsatolás azt a folyamatot jelöli, melynek keretében a felhasználó számára ismertté válik az általa végrehajtott cselekvés eredménye, vagy tudatosul benne a várt érzelmi hatás megtörténte. Korábbi kutatások is arra utalnak, hogy a nonprofit szervezetek marketingtevékenységének fontos szerepe lehet e folyamat gerjesztésében, és a közösségi média mint kommunikációs csatorna alkalmas lehet az ilyen típusú közlések megtételére.

\section{Pilotkutatás a témában}

A témában empirikus előkutatást végeztem, ami a fentebb vázolt modell bizonyos részeit érintette.

\section{Személyiségjegyek és adományozás}

A kutatásban 240 felsőoktatási hallgató vett részt, akik a részvételük fejében extrapontszámokat kaptak egy, az általuk hallgatott tantárgyból. Más ösztönzőt (anyagi stb.) nem alkalmaztunk. A válaszadók feladata kettős volt:

1. A hallgatóknak lájkolniuk kellett egy nonprofit szervezet Facebook-oldalát. Ezt követôen 4 héten át természetes körülmények közt „ki voltak téve” a szervezet által közzétett posztoknak. Ennyi ideig volt alkalmuk találkozni az oldal által megosztott tartalmakkal.

2. Ezt követốen egy speciálisan összeállított kérdôívet kellett kitölteniük, ahol az oldal által megosztott valódi posztokat és fiktív (általam összeállított) álposztokat is értékelniük kellett meghatározott szempontok szerint (a megkérdezetteket nem informáltuk arról, melyik az igazi és melyik az ál poszt). A kutatás keretében azt vizsgáltam: mennyiben képesek helyesen visszaidézni a nem olyan régen (legfeljebb 3-4 hete, de többségében korábban) látott tartalmakat.

A válaszadók személyiségét a társadalmi érzékenység szempontjából vizsgáltuk, aminek eszköze Penner PSB skálája volt (Penner et al., 1995). Ez hét komponensben ragadja meg az egyének társadalmi felelősségvállalási hajlamát: felelósségérzet, empatikus gondolkodás, mások szempontjainak figyelembevételére való képesség, személyes aggodalom, közös erkölcsi érvelés, mások felé irányuló érvelés, illetve önbevalláson alapuló altruizmus. A válaszok alapján a sokaságot nem hierarchikus klaszterelemzés segítségével két különálló klaszterre bontottuk a fenti változók alapján, így sikerült elkülönítenünk egymástól a megkérdezettek szociálisan kevésbé érzékeny (klaszter1, n=88fó) és szociálisan érzékenyebb (klaszter2, n=152 fó) tagjait.
A két klaszter - az előzetes várakozásainknak megfelelóen - másként viszonyult a nonprofit szervezet által a közösségi médiában (Facebook) közzétett üzenetekhez. A méréshez olyan pontrendszert fejlesztettünk ki, melyben minden megkérdezettet egy -2 és 8 közötti skálán értékeltünk, attól függően, hogy a kérdőívben bemutatott Facebook-posztok közül hányat ismert fel (a posztok mindegyike az azt követő időszakból származott, hogy a kutatás első fázisa elindult). (-1)-szeres szorzóval számítottuk az álposztokat, így negatív pontszám is szerezhetô volt.

A két csoportot különböző szempontok szerint vizsgáltam:

- várakozásainknak megfelelóen a társadalmi ügyek iránt érzékenyebb csoport jobban teljesített a már látott posztok felidézésében, pontosabban volt képes azonosítani a látott tartalmakat,

- ugyanakkor vizsgáltam azt is, hogy milyen kognitív folyamatok révén próbálják meg felidézni a már látott tartalmakat (ld. 2. táblázat), eszerint azonban nem volt különbség a két csoport között

\section{2. táblázat}

A megkérdezettek válasza arról, hogy milyen információ alapján igyekeztek azonosítani a látott tartalmakat

\begin{tabular}{|l|c|c|}
\hline \multicolumn{1}{|c|}{ A válasz típusa } & Elófordulás & Arány \\
\hline $\begin{array}{l}\text { Kizárólag a poszthoz tartozó kép } \\
\text { alapján }\end{array}$ & 163 & $67.91 \%$ \\
\hline $\begin{array}{l}\text { Poszthoz tartozó kép és szöveg } \\
\text { alapján }\end{array}$ & 45 & $18.75 \%$ \\
\hline Poszthoz tartozó kép és dátum alapján & 17 & $7.08 \%$ \\
\hline Kizárólag a poszt szövege alapján & 6 & $2.5 \%$ \\
\hline $\begin{array}{l}\text { Poszthoz tartozó kép, szöveg és } \\
\text { dátum alapján }\end{array}$ & 5 & $2.08 \%$ \\
\hline Egyéb & 4 & $1.67 \%$ \\
\hline
\end{tabular}

Forrás: saját szerkesztés

\section{A Facebook marketinghatása az adományozásra}

A kutatás kiterjedt a közösségi média hatékonyságára is az adományozásban. Ennek mérésére az SOS Gyermekfalu adományvonala ${ }^{4}$ és a szervezet Facebook-posztjai közötti összefüggést vizsgáltuk. A vizsgált időszakban ugyanakkor - várakozásainkkal ellentétben - nem sikerült szignifikáns kapcsolatokat feltárni sem a közösségimédia-tevékenység, sem más marketingtevékenység, illetve a beérkezó hívások száma között. Ahogyan az a 4. ábráról is leolvasható, a hívások száma meglehetôsen hektikusan alakult, volt, hogy heteken át egyetlen hívás sem érkezett, majd a rákövetkező héten több felajánlást is tettek. 


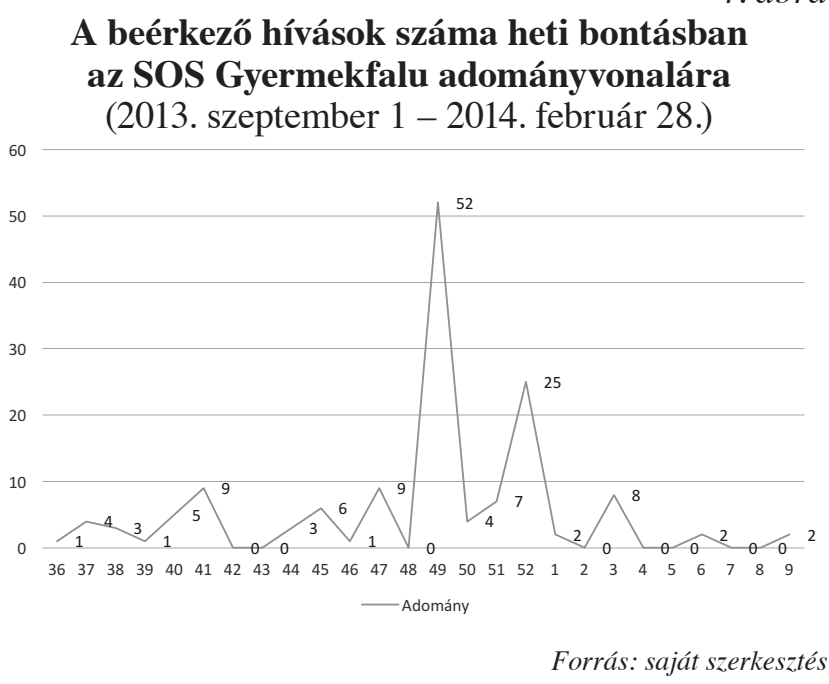

Ennek magyarázatát a moderáló változók feltételezhető erôs hatásában láttuk:

- kulturális tényezók: szemmel láthatóan az adományozási kedv ünnepi idószakban erôsödik meg, a vizsgált időszakban beérkező hívások 59,23 százaléka két hétre összpontosult: a december eleji, Mikulás ünnepet megelőző napok, valamint az év utolsó hete (szilveszter előtt),

- további nehézséget jelenthet, hogy a Facebook Causes Magyarországon nem elérhető alkalmazás, azaz a nonprofit szervezeteknek e népszerú platformon nincs lehetôségük azonnali adománygyújtésre, hanem a pénzgyújtést csak csatornaváltással valósíthatják meg. A kommunikáció a közösségi médiában zajlik, az adományokat azonban telefonálás, SMS-küldés (esetleg átutalás, transzfer stb.) segítségével tudják fogadni.

További vizsgálatot igényel, hogy az üggyel való azonosulás milyen módon befolyásolja a szervezet marketingkampányának hatékonyságát. Az egyszázalékos felajánlások alapján úgy túnik, a magyar társadalom a jótékonyság szempontjából leginkább a beteg gyerekek gyógyítására, valamint az állatok gondozására, ellátására érzékeny.

\section{Összegzés, konklúzió}

Jelen kutatás egyik fontos eredménye a nonprofit szektor, valamint a közösségi média vonatkozó szakirodalmi hátterének összefoglalása. A közösségi hálózatok szerepe egyértelmúen nő nemcsak a for-profit, valamint a kormányzati, de a harmadik szektor szereplői számára is. Ez komoly átalakulásokat indukált már eddig is, valamint további fontos változásokat vetít előre.
A korábbi kutatások alapján saját modellt állítottam fel, melynek empirikus tesztelésére egyelöre nem került sor, ez egy következő kutatás feladata lesz. A tanulmánynak ezen kívül limitációja, hogy a javasolt modellből olyan tényezők kimaradtak, mely szerepek vizsgálata egyébként indokolható lehetne a közösségi médián keresztül folyó impulzusadományozásban. Az egyik fontosabb ilyen tényezőnek a felhasználók kultúráját tartom. Az adományozás és a kultúratípusok kapcsolatát egyébként is kevés tanulmány feszegette még, miközben intuitív módon valószínúsíthető, hogy a kulturális tényező́knek (pl. Hofstede dimenziói) jelentôs szerepük van mind az adományozási gyakorlatban, mind a fogyasztók (adományozók) impulzivitásában. Egy kultúraközi kutatás azonban messze meghaladta ennek a tanulmánynak a kereteit és lehetőségeit.

Az adományokat fogadó nonprofit szervezetek egyes vonásainak vizsgálata meglehetősen sok korábbi kutatásban kapott szerepet magyarázó változóként. Ilyen tényezók voltak a szervezetek által folytatott munka minősége (pl. hatékonyság, adminisztráció stb.), azok kora, megbízhatósága, a magáról közzé tett információ minősége és mennyisége, visszacsatolás az adományozók felé, reklámtevékenység stb. Ezek számos kutatás által igazolt módon, fontos szerepet játszanak a szervezetek adománygyuújtési folyamatában. Jelen kutatásban azért nem vizsgáltam azok szerepét, mivel elsősorban az adományozókra fókuszáltam, és feltételezem, hogy a harmadik szektor nagyszámú szereplője közül lesz olyan, aki számára a „fogyasztó” a felajánlását meg fogja tudni tenni.

Egy újabb korlát a kutatásomban az, hogy az egyébként rendkívül széles skálán mozgó emberi érzelmeknek csupán egy szúkebb spektruma szerepel a modell következménytényezói sorában. Ennek oka az, hogy a szakirodalmi áttekintés során ezekre az érzelmekre találtam példákat korábbi kutatásokban, ugyanakkor szintén valószínúsíthetô, hogy az adományozás által megmozgatott érzelmek ennél jóval szélesebb skálán mozognak. Ezek feltárása szintén egy újabb kutatás témája lehet.

A tanulmányomnak mind a gyakorló, nonprofit szférában aktív menedzserek, mind az akadémiai számára van relevanciája, üzenetértékú megállapítása.

A fontosabb menedzseri következtetések az alábbi pontokban összegezhetók:

1. A közösségi média figyelmet követel magának a harmadik szektor szervezetei részéről is. Ezt indokolják a fogyasztói magatartásban bekövetkező változások, azok, hogy az emberek mind nagyobb számban egyre több időt töltenek a közösségi oldalakon. Fontos vonzerôt jelenthet a váltáshoz az is, hogy a rendszer múködési logikájából eredóen 
a korábbinál olcsóbb, hatékonyabb, jobban célzott kommunikáció, szervezés, adománygyújtés válik lehetôvé.

2. Azt sem szabad viszont elfelejteni, hogy az új közegben már nem a „régi” logika érvényesül. Az adománygyújtés során figyelembe kell venni, hogy a közösségi médiában jellemzően más (fiatalabb) réteg van jelen, és óket nemcsak a generációs, de a kommunikációs csatorna sajátosságai miatt is másként kell megszólítani.

3. Új kihívásokra kell felkészülni. Például korábban a gyújtések során a „slacktivism”/,clicktivism” jelenségnek nem volt más megfelelője.

$\mathrm{Az}$ akadémiai szféra számára, úgy vélem, a nonprofit szektor, valamint a közösségi média keresztmetszete sok érdekes, még feltárásra váró jelenség.

1. A közösségi média és a nonprofit szektor találkozási pontja új, szokatlan kihívásokat és ezért remek kutatási területet jelent.

2. A terület sajátosságai miatt egy sor olyan jelenséget is vizsgálni lehet, ami máskülönben nehezen elhatárolható. A kutatások többsége a for-profit szektorban született, ahol például a nagyobb elérés rendszerint egyben a reklámcélok teljesülését is jelenti. Az első példában bemutatott 'Kony 2012' kampány esetében láttuk: a nonprofit szektorban ez koránt sem biztosított minden esetben.

\footnotetext{
Jegyzet

1 Joseph Kony a „Lord's Resistance Army”, ismertebb magyar nevén az acsoliföldi felkelés vezetője. Az általa vezetett milícia a legalapvetőbb emberi jogokat sem tiszteli: kínzásos vallatásokat hajt végre, valamint számos fogoly megcsonkításával, nemi erôszak elkövetésével, emberrablással, helyi lakosság lemészárlásával is vádolják. Az Invisible Children akciója egy hasonlóan szörnyú jelenségre, a gyermekkatonák bevetésére kívánta ráirányítani a figyelmet, amit a csoport szintén intenzíven 'gyakorol' .

2A „,lacktivism” az angol slack (,laza”, ,tétlenség”, ,,semmittevés”) és az activism (,aktivitás”) szavak kombinációjaként született meg, a clicktivism ennek mintájára a kattintás + aktivizmus szavak összevonásából jött létre. Magyar megfelelóje egyelőre nincs, a fogalomhoz legközelebb talán a politikai szférából ismert „,fotel-forradalmár” kifejezés állhat, amit legygyakrabban szintén az online közegben aktív (pl. gyakran kommenteló), de azon kívül már közönyös „aktivistákra” szoktak használni (pl. nem vesz részt megmozdulásokon, nem támogat személyes jelenlétével ügyeket stb.).

${ }^{3}$ https://www.newscientist.com/article/2079741-a-social-network-built-for-donating-aims-to-fix-slacktivism/

${ }^{4} \mathrm{Az}$ adományvonal egy népszerú támogatási forma, a programot a NIOK Alapítvány koordinálja, múködtetését négy nagy hazai telekommunikációs szolgáltató összefogása teszi lehetővé, a jogi környezetet pedig a Nemzeti Média- és Hírközlési Hatóság (NMHH) szabályozása teremtette meg. Egy hívással vagy SMS küldésével 250,-Ft ajánlható fel a kiválasztott civil szervezetek javára. Az elmúlt években közel ötszázezer felajánlás érkezett a vonalon keresztül több, mint százmillió forint értékben. Forrás: adhatvonal.hu
}

\section{Felhasznált irodalom}

Aaker, J. - Akutsu, S. (2009): Why do people give? The role of identity in giving. Journal of Consumer Psychology, Volume 19, Issue 3, July, p. 267-270.

Aaker, J. - Akutsu, S. - Liu, W. (2009): The Psychology of Giving. Stanford GSB Working papers. p. 1-41.

Bennett, R. (2009): Impulsive donation decisions during online browsing of charity websites. Journal of Consumer Behaviour, 8(2-3), p. 116-134.

Bernritter, S. F. - Verlegh, P. W. J. - Smit, E. G. (2016): Why Nonprofits Are Easier to Endorse on Social Media: The Roles of Warmth and Brand Symbolism. Journal of Interactive Marketing, 33, p. 27-42. http://doi.org/10.1016/j.intmar.2015.10.002

Bowers, C. (2010): The Thinking Behind Our First Email. Blog bejegyzés, Dailykos.com, $\mathrm{Au}-$ gust 17, 2010. http://www.dailykos.com/ storyonly/2010/8/17/893956/-The- thinking-behind-our-first-email. Letöltve: 2016. 05. 06.

Briones, R. L. - Kuch, B. - Liu, B. F. - Jin, Y. (2011): Keeping up with the digital age: How the American Red Cross uses social media to build relationships. Public Relations Review, 37(1), p. 37-43. http://doi. org/10.1016/j.pubrev.2010.12.006

Callen, J. L. - Klein, A - Tinkelman, D. (2003): Board composition, committees, and organizational efficiency: The case of nonprofits. Nonprofit and Voluntary Sector Quarterly, 32(4), p. 493-520.

Collins, E. - Hide, B. (2010): Use and relevance of Web 2.0 resources for researchers. in: Publishing in the Networked World: Transforming the Nature of Communication 14th International Conference on Electronic Publishing. p. 271-289.

Cryder, C. - Loewenstein, G. (2008): Tightwads and spendthrifts. Journal of Consumer Research, 34(6), p. $767-782$

Donthu, N. - Garcia, A. (1999): The internet shopper. Journal of Advertising Research, 39(3), p. 52-58.

Flannery, H. - Harris, R. - Rhine, C. (2009): 2008 DonorCentrics Internet giving benchmarking analysis. Charleston, SC: Target Analytics

Gandia, J.L. (2011): Internet disclosure by nonprofit organizations: Empirical evidence of nongovernmental organizations for development in Spain. Nonprofit and Voluntary Sector Quarterly, 40, p. 57-78.

Greenberg, J. - MacAulay, M. (2009): NPO 2.0? Exploring the Web Presence of Environmental Nonprofit Organizations in Canada. Global Media Journal, 2(1), p. 63-88.

Guo, C. - Saxton, G. D. (2013): Tweeting social change: How social media are changing nonprofit advocacy. Nonprofit and Voluntary Sector Quarterly, XX(X), p. 1-23. DOI: 10.1177/0899764012471585 
Hibbert, S. et al. (2007): Guilt appeals: Persuasion knowledge and charitable giving. Psychology \& Marketing, 24.8, p. 723-742.

Hudson, S. - Thal, K. (2013): The impact of social media on the consumer decision process: Implications for tourism marketing. Journal of Travel \& Tourism Marketing, 30(1-2), p. 156-160.

Ilten, C. (2015): Use Your Skills to Solve This Challenge!: The Platform Affordances and Politics of Digital Microvolunteering. Social Media+ Society, July-December, p. 1-11. DOI: 10.1177/2056305115604175

Liu, W. - Aaker, J. (2008): The happiness of giving: The time-ask effect. Journal of Consumer Research, 35(3), p. 543-557.

Mejova, Y. - Garimella, V. R. K. - Weber, I. - Dougal, M. C. (2014): Giving is caring: understanding donation behavior through email. in: Proceedings of the 17th ACM conference on Computer supported cooperative work \& social computing. ACM., p. 1297-1307.

Morozov, E. (2009): The Brave New World of Slacktivism. Foreign Policy, May 19, 2009. http://neteffect.foreignpolicy.com/posts/2009/05/19/ the_brave_new_ world_of_slacktivism. Letöltve: 2016. 05. 06.

Oliver, R. L. (1980): A cognitive model of the antecedents and consequences of satisfaction decisions. Journal of Marketing Research, Vol. 17, No. 4, Nov., p. 460-469.

Paulin, M. - Ferguson, R. J. - Schattke, K. (2014): Millennials, Social Media, Prosocial Emotions, and Charitable Causes : The Paradox of Gender Differences. Journal of Nonprofit \& Public Sector Marketing, Volume 26, Issue 4, p. 335-353.

O'Reilly, T. (2005): What Is Web 2.0? Design Patterns and Business Models for the Next Generation of Software. Elérhető: http://www.oreilly.com/pub/a/ web2/archive/what-is-web-20.html Letöltve: 2016. június 11.

Penner, L. A. - Fritzsche, B. A. - Craiger, J. P. - Freifeld, T. R. (1995): Measuring the prosocial personality. Advances in personality assessment, 10, p. 147163.

Picazo-Vela, S. - Gutierrez-Martinez, I. - Luna-Reyes, L. F. (2012): Understanding risks, benefits, and strategic alternatives of social media applications in the public sector. Government Information Quarterly, 29(4), p. 504-511.

Roberts, A. A. - Smith, P. - Taranto, K. (2005): Marginal versus average spending in charities. Unpublished working paper.

Rowlands, I. - Nicholas, D. - Russell, B. - Canty, N. - Watkinson, A. (2011): Social media use in the research workflow. Learned Publishing, 24(3), p. 183-
195.

Saxton, G. D. - Guo, C. (2014): Online stakeholder targeting and the acquisition of social media capital. International Journal of Nonprofit and Voluntary Sector Marketing, 19(4), p. 286-300.

Saxton, G. D. - Guo, C. (2014): Online stakeholder targeting and the acquisition of social media capital. International Journal of Nonprofit and Voluntary Sector Marketing, October, p. 286-300.

Saxton, G. D. - Wang, L. (2014): The Social Network Effect: The Determinants of Giving Through Social Media. Nonprofit and Voluntary Sector Quarterly, Vol 43, Issue 5, p. 850-868.

Schiffman, L. G. - Kanuk, L. L. (2000): Consumer Behaviour. Upper Saddle River, NJ: Prentice Hall

Shulman, S. (2009): The Case Against Mass E-mails: Perverse Incentives and Low Quality Public Participation in U.S. Federal Rulemaking. Policy \& Internet 1 (1), p. 23-53.

Small, D. A. - Loewenstein, G. - Slovic, P. (2007): Sympathy and callousness: The impact of deliberative thought on donations to identifiable and statistical victims. Organizational Behavior and Human Decision Processes, 102(2), p. 143-153.

Stenger, T. - Coutant, A. (2010): Les réseaux sociaux numériques: des discours de promotion à la définition d'un objet et d'une méthodologie de recherche. Hermes-Journal of Language and Communication Studies, 44, p. 209-228.

Tinkelman, D. - Mankaney, K. (2007): When is administrative efficiency associated with charitable donations? Nonprofit and Voluntary Sector Quarterly, 36(1), p. 41-64.

Vijaykumar, S. - Wray, R. J. - Buskirk, T. - Piplani, H. - Banerjee, J. - Furdyk, M. - Pattni, R. (2014): Youth, new media, and HIV/AIDS: Determinants of participation in an online health social movement. Cyberpsychology, Behavior, and Social Networking, 17(7), p. 488-495. http://doi.org/10.1089/cyber.2013.0124

Waters, R. D. (2009): The use of social media by nonprofit organizations: An examination from the diffusion of innovations perspective. in: Social computing: Concepts, methodologies, tools, and applications. Hershey, PA: IGI Global, p. 1420-1432.

Waters, R. D. - Burnett, E. - Lamm, A. - Lucas, J. (2009): Engaging stakeholders through social networking: How nonprofit organizations are using $\mathrm{Fa}-$ cebook. Public Relations Review, 35(2), p. 102-106.

Waters, R. D. - Tindall, N. T. - Morton, T. S. (2010): Media catching and the journalist-public relations practitioner relationship: How social media are changing the practice of media relations. Journal of Public Relations Research,22(3), p. 241-264. 
Weinberg, P. - Gottwald, W. (1982): Impulsive consumer buying as a result of emotions. Journal of Business Research, 10(1), p. 43-57.

Weisbrod, B.A. - Dominguez, N.D. (1986): Demand for collective goods in private nonprofit markets: Can fundraising expenditures help overcome free-rider behavior? Journal of Public Economics, 30(1), p. 83-96. http://doi.org/10.1016/0047-2727(86)90078-2
White, K. - Peloza, J. (2009): Self-Benefit Versus Other-Benefit Marketing Appeals: Their Effectiveness in Generating Charitable Support. Journal of Marketing, 73(July), p. 109-124. http://doi.org/10.1509/ jmkg.73.4.109

$Y e$, N. - Teng, L. - Yu, Y. - Wang, Y. (2015): What's in it for me?: The effect of donation outcomes on donation behavior. Journal of Business Research, 68(3), p. 480-486.

\section{E SZÁMUNK SZERZŐI}

Zsótér Boglárka, egyetemi tanársegéd, Budapesti Corvinus Egyetem; Dr. Bauer András, PhD, egyetemi tanár, Budapesti Corvinus Egyetem; Dr. Kemény Ildikó, PhD, egyetemi adjunktus, Budapesti Corvinus Egyetem; Dr. Kolos Krisztina, Ph.D, egyetemi docens, Budapesti Corvinus Egyetem; Dr. Kenesei Zsófia, Ph.D, egyetemi docens, Budapesti Corvinus Egyetem; Szilvai Zsolt, UX/UI designer, UX Studio; Dr. Agárdi Irma, PhD, egyetemi docens, Budapesti Corvinus Egyetem; Dr. Gyulavári Tamás, $\mathrm{PhD}$, egyetemi docens, Budapesti Corvinus Egyetem; Seprődi Patrícia, közgazdász, Quality \& Process management osztályvezető, Erste Bank Hungary Zrt.; Hubert József, PhD-hallgató, Budapesti Corvinus Egyetem 